\title{
Relationship between the properties of raw and cooked spaghetti - new indices for pasta quality evaluation
}

\author{
Beata Biernacka ${ }^{1}$, Dariusz Dziki ${ }^{*}$, Renata Różyło ${ }^{2}$, Monika Wójcik ${ }^{2}$, Antoni Miś3 ${ }^{3}$, Daria Romankiewicz ${ }^{4}$, \\ and Zbigniew Krzysiak \\ ${ }^{1}$ Department of Thermal Technology and Food Process Engineering, ${ }^{2}$ Department of Equipment Operation and Maintenance \\ in the Food Industry; University of Life Sciences, Doświadczalna 44, 20-280 Lublin, Poland \\ ${ }^{3}$ Institute of Agrophysics, Polish Academy of Sciences, Doświadczalna 4, 20-290 Lublin, Poland \\ ${ }^{4}$ Division of Cereal Technology, Faculty of Food Sciences, Warsaw University of Life Sciences, Nowoursynowska 159C, Warsaw, Poland \\ ${ }^{5}$ Department of Mechanical Engineering and Automatics, University of Life Sciences in Lublin, Głęboka 28, Lublin, Poland
}

Received July 4, 2017; accepted December 29, 2017

\begin{abstract}
A b s t r a c t. The quality of pasta can be evaluated by measuring the characteristics which encompass the most important quality parameters, such as colour, cooking properties and texture. The aim of the study was to suggest new indices which can be used to evaluate the quality of pasta. For the tests, 15 samples of spaghetti (produced from either semolina or common wheat flour) were used. The bending test was performed for the determination of the strength properties of raw pasta, while the pasta colour parameters were evaluated via the Commission Internationale de l'Eclairage system. The pasta cooking test included the evaluation of optimum cooking time, weight increase index and cooking loss. The samples of cooked spaghetti were cut, and the parameters describing pasta texture were determined. Statistical analysis showed significant correlations $(\alpha=0.05)$ between colour parameters (lightness and redness) and pasta ash content $(\mathrm{R}=$ -0.90 and 0.84 , respectively). The mechanical properties of raw pasta correlated positively with pasta density. The strongest correlation was found between pasta density and flexural strength. The destruction force for raw spaghetti during the bending test correlated significantly and positively with the cutting force of the cooked pasta. The obtained correlations can be helpful in pasta quality evaluation.

K e y w o r d s: pasta, mechanical properties, colour, cooking, quality
\end{abstract}

\section{INTRODUCTION}

Pasta is a popular food because of its ease of preparation, sensory appeal, low cost and storage stability (Martinez et al., 2007). Compared to other starch-based foods, pasta has

\footnotetext{
*Corresponding author e-mail: dariusz.dziki@up.lublin.pl
}

beneficial physiological effects, as seen by low glycemic and insulinemic responses (Aston et al., 2008; Krishnan and Prabhasankar, 2012). It is a very simple food usually composed of only water and durum wheat semolina or common wheat flour. The best quality pasta is made of durum wheat semolina with a low enzyme activity and a yellowish colour. Semolina is an expensive material, thus pasta is often produced from common wheat flour (Triticum aestivum, ssp. vulgare), but the product obtained from such flour is usually characterised by poorer cooking quality (Biernacka et al., 2017).

Quality evaluation of pasta includes a series of tests based on the determination of physicochemical and cooking properties, as well as nutritional and sensory evaluation. The sensory analysis of pasta is an important quality criterion by which consumers can judge their acceptability. Generally, the consumer is looking for pasta with a firm bite, good mouth feel (not too hard, but should not immediately disintegrate in the mouth), that which is not sticky or -gummy; with a good aroma, colour and appearance (Raina et al., 2005). However, with regard to sensory evaluation, a scientific approach is difficult, because the reference parameters are strongly affected by the market, for example, the preferences of the North-American consumer are very different from the European one (Feillet et al., 2000; Migliori et al., 2005).

(C) 2018 Institute of Agrophysics, Polish Academy of Sciences 
Pasta colour is an essential quality parameter. The coour of pasta (without additives) strongly depends on the properties of the composing flour or semolina - specifically, the carotenoids content and protein composition (Ohm et al., 2008). Generally, consumers prefer pasta with a bright yellow colour (Debbouz et al., 1993). Parameters describing the textural characteristics of pasta are also very important quality indicators for consumers, as different people prefer pasta with a varying firmness after cooking. The texture of raw and cooked pasta has been reported to be influenced by the quality of raw materials (Raina et al., 2005). The instrumental evaluation of cooked pasta texture is the most objective method and includes a series of tests such as the cutting test (Larrosa et al., 2016) and the compression test (Bouasla et al., 2017). The indices obtained on the basis of such tests: firmness, cohesiveness, springiness, viscosity and adhesiveness depend on the equally interacting raw-material composition, as well as the technology of production and conditions of cooking (Biernacka et al., 2017). There are few studies concerning the texture evaluation of raw pasta. Hollgier (1963) was first to propose a test device for the mechanical characteristics of raw pasta, doing so on the basis of the bending test. He showed that this kind of test should be carried out for trials in which the same water content is held. For raw pasta, two instrumental parameters were reported by Walsh (1971). These are based on the cutting pasta curve: peak height and the area under the curve. Such parameters are strongly correlated with pasta susceptibility to breaking during packaging and shipping. The aim of this study was to evaluate the relationships between the properties of pasta before and after cooking, especially the relationships between the mechanical properties, colour and cooking properties of spaghetti.

\section{MATERIALS AND METHODS}

Fifteen types of pasta made by different producers, either of semolina or common wheat flour and wholegrain flour were used (Table 1). All pasta was properly packed. All packages showed information about the ingredients and the 'best before' date.

The initial content of pasta moisture was determined by drying samples of spaghetti at $105^{\circ} \mathrm{C}$ up to constant mass. The chemical composition of the pasta products was then determined according to AACC Approved Methods (2000). These determinations included the total protein content (AACC, Method 46-08), ash content (AACC, Method 08-01) and fat content (AACC, Method 30-26; hexane solvent used). Such analyses were performed in triplicate.

Table 1. Characteristics of the analysed pasta

\begin{tabular}{|c|c|c|c|c|c|c|}
\hline \multirow{2}{*}{ Sample No. } & \multirow{2}{*}{ Producer } & \multicolumn{2}{|c|}{ Main component } & \multirow{2}{*}{$\begin{array}{c}\text { Other } \\
\text { components } \\
\text { (except water) }\end{array}$} & \multirow{2}{*}{$\begin{array}{l}\text { Initial moisture } \\
\quad(\% \mathrm{wb})\end{array}$} & \multirow{2}{*}{$\begin{array}{l}\text { Recommended } \\
\text { time of cooking } \\
\text { (min) }\end{array}$} \\
\hline & & $\begin{array}{c}\text { common wheat } \\
\text { flour }\end{array}$ & semolina & & & \\
\hline I & Pol-Mak & + & - & - & $9.84 \pm 0.25$ & 7 \\
\hline II & Solare & + & - & - & $10.06 \pm 0.27$ & 7 \\
\hline III & Tesco value & + & - & - & $9.7 \pm 0.09$ & 8 \\
\hline IV & Tradycyjny Spaghetti & + & - & - & $8.76 \pm 0.21$ & 7 \\
\hline $\mathrm{V}$ & Wiodąca marka & - & + & - & $11.52 \pm 0.22$ & 10 \\
\hline VI & Arrighi & - & + & - & $9.39 \pm 0.16$ & 8 \\
\hline VII & Barilla & - & + & - & $8.93 \pm 0.23$ & 8 \\
\hline VIII & Agnesi & - & + & - & $9.42 \pm 0.22$ & 10 \\
\hline IX & As - Babuni & - & + & - & $10.28 \pm 0.17$ & 10 \\
\hline$X$ & Riscossa & - & + & - & $11.21 \pm 0.22$ & 6 \\
\hline XI & Lubella & - & + & - & $9.97 \pm 0.17$ & 11 \\
\hline XII & Sorenti & - & + & - & $11.32 \pm 0.11$ & 9 \\
\hline XIII & Malma & - & + & - & $9.33 \pm 0.20$ & 8 \\
\hline XIII & Malma & - & + & - & $9.18 \pm 0.18$ & 6 \\
\hline XV & Lubella & wholegrain flour & - & - & $8.92 \pm 0.08$ & 12 \\
\hline
\end{tabular}

I-IV - common wheat pasta, V-XIV - durum wheat pasta, XV - wholemeal durum wheat pasta. 
Raw pasta dimensions (length and diameter) were measured using a computer vision system (Różyło et al., 2015). Measurements were conducted on 10 strands of spaghetti. Its density was calculated from the measured dimensions and the weight of pasta, assuming the cylindrical shape of spaghetti.

Colour was measured in five repetitions for every kind of pasta before cooking, by using a colourimeter (Chroma Meter CR-400C, Minolta, Osaka, Colour Lab, Japan). The following parameters were recorded: $L^{*}, a^{*}$ and $b^{*}$. The former, $L^{*}$, is the lightness coordinate, ranging from no reflection for black $\left(L^{*}=0\right)$ to perfect diffuse reflection for white $\left(L^{*}=100\right)$. The middle, $a^{*}$, is the redness coordinate, ranging from negative values for green to positive values for red. The last, $b^{*}$, is the yellowness coordinate, ranging from negative values for blue to positive values for yellow (Horváth and Hodúr, 2007).

The bending test of raw pasta was performed in a strength tester Z020/TN2S (ZWICK, Ulm-Einsingen, Germany). Measurements were carried out on raw samples of spaghetti with moisture $11 \% \pm 0.2$ (wb). In order to obtain similar levels of pasta moisture, the spaghetti samples were put into a climatic chamber for two weeks (temperature $20^{\circ} \mathrm{C}$, air humidity $60 \%$ ). A single sample of spaghetti with a length of about $12 \pm 0.3 \mathrm{~cm}$ was then put on two spherical supports, with the distance between the supports $(L)$ being $8 \mathrm{~cm}$. The knife (2 $\mathrm{mm}$ thick) was subsequently moved in a plane perpendicular to the pasta sample in the middle distance between supports (Fig. 1). The head speed was $20 \mathrm{~mm} \mathrm{~min}^{-1}$. The range measuring head was $100 \mathrm{~N}$. For every sample of pasta, ten repeated measurements were performed.

Based on the obtained characteristics, the following mechanical parameters were determined: the maximum deflection of the centre of the spaghetti $\left(h_{\max }\right)$, maximum force $\left(F_{\max }\right)$ and deformation work $\left(W_{d}\right)$. The flexural strength $(\sigma)$ of the spaghetti was calculated as follows:

$$
\sigma=\frac{M_{g}}{W_{z}}
$$

where: $M_{g}$ is a bending moment:

$$
M_{g}=\frac{F_{\max } L}{4},
$$

and $W_{z}$ is flexural modulus:

$$
W_{z}=\frac{\pi d^{3}}{32}
$$

where $d$ is the diameter of raw pasta.

For evaluating the cooking properties, $100 \mathrm{~g}$ of each spaghetti was cooked in 11 of boiling distilled water. The amount of water absorbed during cooking was measured as the weight increase of pasta after cooking. The weight increase index was then calculated by dividing the weight

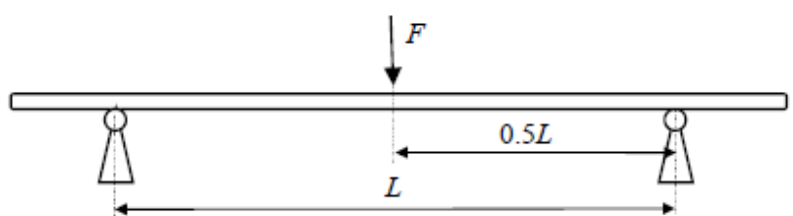

Fig. 1. Raw spaghetti sample loading during the bending test.

of pasta after cooking by the weight of uncooked pasta (Bonomi et al., 2012). Cooking loss was measured by evaporating the cooking water to dryness in an oven-dry method (66-50.01 method; AACC, 2011). The optimum cooking time of pasta was determined by the disappearance of the white central core of the pasta (Sobota et al., 2015). These analyses were performed in triplicate.

Texture analysis was performed in a strength tester Z020/ TN2S (ZWICK, Ulm-Einsingen, Germany). For every sample of pasta, ten repeated measurements were carried out. Measurements were carried out on cold samples (room temperature). Samples were first dipped in cool water soon after cooking (Larrosa et al., 2016), a single sample of pasta was then put on the bottom plate of a resistance testing machine (Zwick Z020) and cut with a knife (1 mm thick) at a crosshead speed of $10 \mathrm{~mm} \mathrm{~min}^{-1}$ until the distance between the knife and the plate was $0.2 \mathrm{~mm}$. The test was used to determine the maximum force and shear work needed to cut the single cooked pasta sample. The detailed description of the procedure used was described by Dziki and Laskowski (2005).

The results were expressed as mean \pm S.D. One-way analysis of variance (ANOVA) and Tukey's post-hoc test were used to compare groups (STATISTICA 13, StatSoft, Inc., Tulsa, USA). Pearson's correlation coefficients were also determined. Statistical analyses were performed at a significance level of $\alpha=0.05$.

\section{RESULTS AND DISCUSSION}

The results of tests of the basic chemical composition of raw pasta products are shown in Table 2. The initial moisture of spaghetti ranged from $8.76 \%$ (sample IV) to $11.52 \%$ (sample V) (Table 1). Spaghetti obtained from semolina was characterised by higher protein content than the pasta produced from common wheat flour. The highest protein content $(16.33 \%)$ was found in the wholegrain pasta (sample XV), and the lowest amount of this component was reported in sample I (11.04\%). Low protein content (below $10 \%$ ) can increase the brittleness and fragility of these products, and negatively affects their cooking characteristics (Del Nobile et al., 2005; Lucisano et al., 2008).

The fat content of most pasta samples was on a similar level of around $0.25 \%$. A higher content of fat was found $(0.56 \%)$ only in the wholemeal pasta samples. The ash content of the pasta ranged from $0.46 \%$ (sample II) to $1.65 \%$ (sample XV). The ash content in spaghetti obtained from 
Table 2. Basic characteristics of pasta

\begin{tabular}{|c|c|c|c|c|c|}
\hline \multirow{2}{*}{ Sample } & Protein content & Fat content & Ash & \multirow{2}{*}{$\begin{array}{l}\text { Diameter } \\
(\mathrm{mm})\end{array}$} & \multirow{2}{*}{$\begin{array}{l}\text { Density } \\
\left(\mathrm{kgm}^{-3}\right)\end{array}$} \\
\hline & \multicolumn{3}{|c|}{$(\%)$} & & \\
\hline I & $11.04 \mathrm{a} \pm 0.19$ & $0.30 \mathrm{c} \pm 0.01$ & $0.55 \mathrm{abc} \pm 0.04$ & $1.81 \mathrm{~b} \pm 0.02$ & $1352.32 \mathrm{a} \pm 10.12$ \\
\hline II & $12.27 b c \pm 0.10$ & $0.26 \mathrm{abc} \pm 0.02$ & $0.46 \mathrm{a} \pm 0.03$ & $1.82 \mathrm{~b} \pm 0.03$ & $1393.18 \mathrm{~cd} \pm 12.27$ \\
\hline III & $12.83 \mathrm{~cd} \pm 0.22$ & $0.26 \mathrm{ab} \pm 0.02$ & $0.54 \mathrm{ab} \pm 0.03$ & $1.79 b \pm 0.03$ & $1420.06 \mathrm{ef} \pm 9.68$ \\
\hline IV & $11.77 b \pm 0.19$ & $0.25 \mathrm{bc} \pm 0.01$ & $0.59 b c \pm 0.02$ & $1.81 \mathrm{~b} \pm 0.03$ & $1412.31 \mathrm{de} \pm 8.42$ \\
\hline $\mathrm{V}$ & $13.43 \mathrm{def} \pm 0.21$ & $0.27 \mathrm{abc} \pm 0.01$ & $0.94 \mathrm{e} \pm 0.06$ & $1.51 \mathrm{a} \pm 0.04$ & $1450.53 \mathrm{~g} \pm 11.64$ \\
\hline VI & $14.46 \mathrm{hi} \pm 0.15$ & $0.26 \mathrm{abc} \pm 0.01$ & $0.95 \mathrm{e} \pm 0.06$ & $1.79 b \pm 0.05$ & $1391.88 \mathrm{~cd} \pm 11.37$ \\
\hline VII & $14.61 \mathrm{i} \pm 0.19$ & $0.25 \mathrm{abc} \pm 0.01$ & $0.94 \mathrm{e} \pm 0.06$ & $1.82 \mathrm{~b} \pm 0.04$ & $1358.16 \mathrm{ab} \pm 8.86$ \\
\hline VIII & $15.32 \mathrm{j} \pm 0.23$ & $0.23 \mathrm{ab} \pm 0.02$ & $0.95 \mathrm{e} \pm 0.03$ & $1.81 \mathrm{~b} \pm 0.04$ & $1398.96 \mathrm{cde} \pm 10.64$ \\
\hline IX & $13.61 \mathrm{efg} \pm 0.11$ & $0.24 \mathrm{ab} \pm 0.02$ & $0.73 \mathrm{~d} \pm 0.04$ & $1.51 \mathrm{a} \pm 0.05$ & $1365.42 \mathrm{ab} \pm 9.69$ \\
\hline $\mathrm{X}$ & $13.04 \mathrm{de} \pm 0.20$ & $0.26 \mathrm{abc} \pm 0.02$ & $0.93 \mathrm{e} \pm 0.04$ & $1.90 \mathrm{c} \pm 0.06$ & $1440.43 \mathrm{fg} \pm 13.38$ \\
\hline XI & $15.36 \mathrm{j} \pm 0.18$ & $0.21 \mathrm{a} \pm 0.02$ & $0.68 \mathrm{~cd} \pm 0.04$ & $1.91 \mathrm{c} \pm 0.05$ & $1363.81 \mathrm{ab} \pm 12.2$ \\
\hline XII & $14.24 \mathrm{ghi} \pm 0.19$ & $0.25 \mathrm{ab} \pm 0.01$ & $0.91 \mathrm{e} \pm 0.06$ & $1.91 \mathrm{c} \pm 0.04$ & $14210.75 . \mathrm{ef} \pm 12.73$ \\
\hline XIII & $15.91 \mathrm{jk} \pm 0.11$ & $0.25 \mathrm{ab} \pm 0.03$ & $0.95 \mathrm{e} \pm 0.04$ & $1.95 \mathrm{bc} \pm 0.03$ & $1363.26 \mathrm{ab} \pm 7.70$ \\
\hline XIV & $13.87 \mathrm{fgh} \pm 0.23$ & $0.42 \mathrm{~d} \pm 0.03$ & $1.17 \mathrm{f} \pm 0.05$ & $1.81 \mathrm{~b} \pm 0.02$ & $1382.41 b c \pm 9.42$ \\
\hline XV & $16.28 \mathrm{k} \pm 0.25$ & $0.56 \mathrm{e} \pm 0.02$ & $1.66 \mathrm{~g} \pm 0.05$ & $1.98 \mathrm{c} \pm 0.02$ & $1343.67 \mathrm{a} \pm 7.68$ \\
\hline
\end{tabular}

Explanations as in Table 1.

common wheat flour was significantly lower than the content of this component in the pasta produced from durum wheat semolina. A similar tendency was observed by other authors (Martinez et al., 2007). This is due to the fact that endosperm of durum wheat usually contains higher ash content than the endosperm of common wheat grains. High ash content of pasta can also result from the application of flour with a higher yield.

The colour of pasta is one of the main basic discriminates of its quality. It depends mainly on the raw materials used. In considering the results of the colour coordinates (Table 3 ), it was found that the lightness of pasta $\left(L^{*}\right)$ changed in the range from 44.5 (sample XIV) to 62.9 (sample IX). Generally, slightly higher values of $L^{*}$ were obtained for spaghetti made of common wheat flour, in comparison to the values of this parameter for pasta made of durum wheat semolina. A negative and significant correlation was found between the ash content and $L^{*}(\mathrm{R}=-0.899)$. Pasta with the higher ash content was characterised by darker colour (Fig. 2). The redness ( $\left.a^{*}\right)$ of pasta included a range from 6.7 to 12.7 (sample II and XIII, respectively). Pasta obtained from common wheat flour was characterised by lower values of this parameter than the pasta produced from durum wheat. A similar trend was found when examining the value of pasta yellowness $\left(b^{*}\right)$, where the values changed in the range from 25 to 41 (sample IV and VI, respectively).
This study revealed a positive and significant correlation between the redness of pasta and spaghetti ash content (Fig. $3, \mathrm{R}=0.84$ ). The dominant factor determining the colour of pasta is the presence in flour or semolina of the natural dyes carotenoids and xanthophylls, as well as the molecular composition of constituent proteins (Ohm et al., 2008). The properties of the flour or semolina, such as granulation, ash content or starch damage, also affect the colour of pasta (Feillet et al., 2000; Hatcher et al., 2008; Hrušková et al., 2011). Furthermore, the colour of pasta is affected by the additives used (Biernacka et al., 2017).

An important factor determining the colour of pasta is the technological process, and, in particular, the conditions of drying. The selection of the drying method has a significant impact on the quality of the final products. Research presented by Güler et al. (2002) has shown that changes in starch during drying at high temperature can affect the quality of the cooked pasta. This is because the effect of low, high and very high drying temperature affects the development of the Maillard reaction products, which directly affects the colour of pasta (Anese et al., 1999).

The cooking time given by the manufacturer in the case of most trials was significantly lower than the optimal cooking time designated in the studies (Tables 1 and 3). The optimum cooking time of spaghetti ranged between 10.0 and $11.5 \mathrm{~min}$ 
T a b l e 3. Colour parameters and cooking properties of the tested pasta

\begin{tabular}{|c|c|c|c|c|c|c|}
\hline Sample & $L^{*}$ & $a^{*}$ & $b^{*}$ & $t_{o}(\min )$ & $W I$ & $C L(\%)$ \\
\hline I & $60.63 \mathrm{i} \pm 0.33$ & $26.12 \mathrm{ab} \pm 0.75$ & $7.22 \mathrm{ab} \pm 0.45$ & $11.27 \mathrm{~b} \pm 0.29$ & $2.63 \mathrm{ab} \pm 0.31$ & $6.01 \mathrm{fg} \pm 0.15$ \\
\hline II & $62.12 \mathrm{jk} \pm 0.26$ & $26.83 \mathrm{ab} \pm 0.81$ & $6.84 a \pm 0.46$ & $10.83 a \pm 0.29$ & $2.68 \mathrm{ab} \pm 0.19$ & $5.6 \mathrm{def} \pm 0.21$ \\
\hline III & $60.24 \mathrm{hi} \pm 0.28$ & $27.56 \mathrm{abc} \pm 1.51$ & $7.27 \mathrm{ab} \pm 0.38$ & $11.46 \mathrm{~b} \pm 0.00$ & $2.64 a \pm 0.26$ & $6.55 \mathrm{~h} \pm 0.17$ \\
\hline IV & $61.12 \mathrm{ij} \pm 0.45$ & $24.88 \mathrm{a} \pm 0.66$ & $6.78 \mathrm{a} \pm 0.32$ & $9.82 \mathrm{a} \pm 0.76$ & $2.62 \mathrm{ab} \pm 0.20$ & $6.41 \mathrm{gh} \pm 0.19$ \\
\hline $\mathrm{V}$ & $58.88 \mathrm{fg} \pm 0.47$ & $36.32 \mathrm{def} \pm 0.92$ & $8.42 \mathrm{ab} \pm 0.46$ & $10.71 \mathrm{a} \pm 0.29$ & $2.72 \mathrm{ab} \pm 0.27$ & $5.75 \mathrm{ef} \pm 0.14$ \\
\hline VI & $56.47 \mathrm{~d} \pm 0.35$ & $41.27 \mathrm{~g} \pm 1.57$ & $11.33 \mathrm{~cd} \pm 0.75$ & $10.76 \mathrm{a} \pm 0.29$ & $2.85 \mathrm{ab} \pm 0.19$ & $5.31 \mathrm{bcde} \pm 0.16$ \\
\hline VII & $59.33 \mathrm{gh} \pm 0.34$ & $41.04 f g \pm 0.94$ & $9.57 b c \pm 0.61$ & $10.02 \mathrm{a} \pm 0.00$ & $2.79 \mathrm{ab} \pm 0.31$ & $5.21 \mathrm{bcd} \pm 0.12$ \\
\hline VIII & $57.78 \mathrm{ef} \pm 0.23$ & $39.71 \mathrm{efg} \pm 0.83$ & $9.29 b c \pm 0.68$ & $11.31 \mathrm{~b} \pm 0.29$ & $2.72 \mathrm{ab} \pm 0.24$ & $5.58 \mathrm{def} \pm 0.19$ \\
\hline IX & $62.87 \mathrm{k} \pm 0.40$ & $32.04 \mathrm{~cd} \pm 1.35$ & $7.27 \mathrm{ab} \pm 0.37$ & $10.52 \mathrm{a} \pm 0.00$ & $2.77 \mathrm{ab} \pm 0.22$ & $6.01 \mathrm{fg} \pm 0.18$ \\
\hline $\mathrm{X}$ & $57.46 \mathrm{ef} \pm 0.34$ & $38.52 \mathrm{efg} \pm 1.44$ & $9.40 \mathrm{bc} \pm 0.67$ & $11.27 b \pm 0.29$ & $2.67 \mathrm{a} \pm 0.19$ & $5.33 \mathrm{bcde} \pm 0.21$ \\
\hline XI & $57.83 \mathrm{fg} \pm 0.28$ & $35.87 \mathrm{de} \pm 0.98$ & $9.12 \mathrm{abc} \pm 0.84$ & $10.84 a \pm 0.29$ & $2.89 \mathrm{ab} \pm 0.15$ & $5.53 \mathrm{cde} \pm 0.23$ \\
\hline XII & $58.77 \mathrm{c} \pm 0.37$ & $39.43 \mathrm{efg} \pm 1.74$ & $8.08 \mathrm{ab} \pm 0.39$ & $10.78 \mathrm{a} \pm 0.29$ & $2.63 \mathrm{ab} \pm 0.35$ & $5.13 \mathrm{abc} \pm 0.16$ \\
\hline XIII & $53.82 \mathrm{c} \pm 0.34$ & $41.12 \mathrm{fg} \pm 1.56$ & $8.04 \mathrm{ab} \pm 0.43$ & $11.33 \mathrm{~b} \pm 0.29$ & $2.70 \mathrm{ab} \pm 0.12$ & $4.76 \mathrm{a} \pm 0.14$ \\
\hline XIV & $50.51 \mathrm{a} \pm 0.19$ & $31.91 \mathrm{~cd} \pm 1.46$ & $12.66 \mathrm{~d} \pm 0.62$ & $10.47 \mathrm{a} \pm 0.29$ & $3.00 \mathrm{~b} \pm 0.18$ & $5.38 \mathrm{cde} \pm 0.23$ \\
\hline XV & $44.47 \mathrm{~b} \pm 0.21$ & $30.89 b c \pm 1.47$ & $12.64 \mathrm{~d} \pm 0.65$ & $11.0 \pm 0.00$ & $2.63 \mathrm{ab} \pm 0.22$ & $4.92 \mathrm{ab} \pm 0.18$ \\
\hline
\end{tabular}

$L^{*}$ - lightness, $a^{*}$ - redness, $b^{*}$ - yellowness, $t_{o}$ - optimum cooking time, $W I-$ weight increase index, $C L-$ cooking loss. Other explanations as in Table 1 .

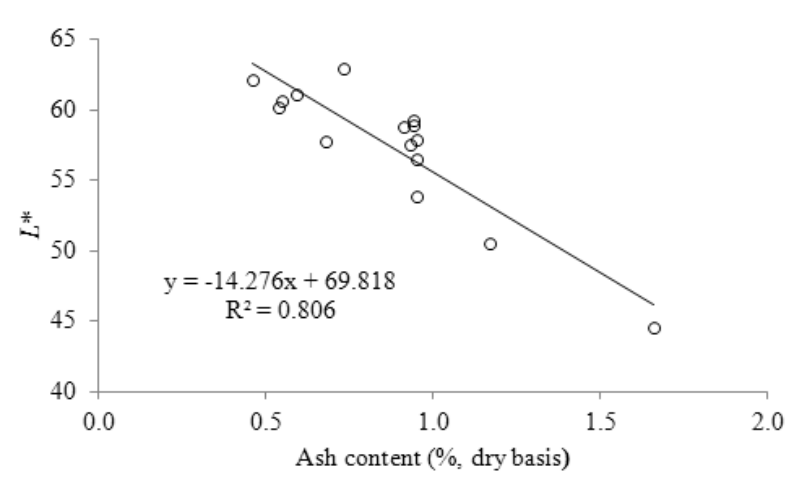

Fig. 2. Relationship between the ash content and lightness of pasta.

The weight increase index of pasta ranged from 2.62 to 3.00 , whereas the cooking loss $(C L)$ changed from 4.76 to $6.55 \%$ (Table 3 ). Significant correlations were found between $C L$ and pasta lightness $(\mathrm{R}=0.62)$, redness $(\mathrm{R}=$ $-0.73)$ and yellowness $(R=0.75)$. Generally, slightly higher values of $C L$ were obtained for pasta made of common wheat flour than for spaghetti made of durum wheat. This tendency is in agreement with our previous study (Dziki et al., 2012). This fact could be explained by the lower protein content in pasta made of common wheat flour. A significant and negative correlation was found between protein content and $C L(\mathrm{R}=-0.69)$. Lower protein content results in a weaker protein matrix and higher $C L$.

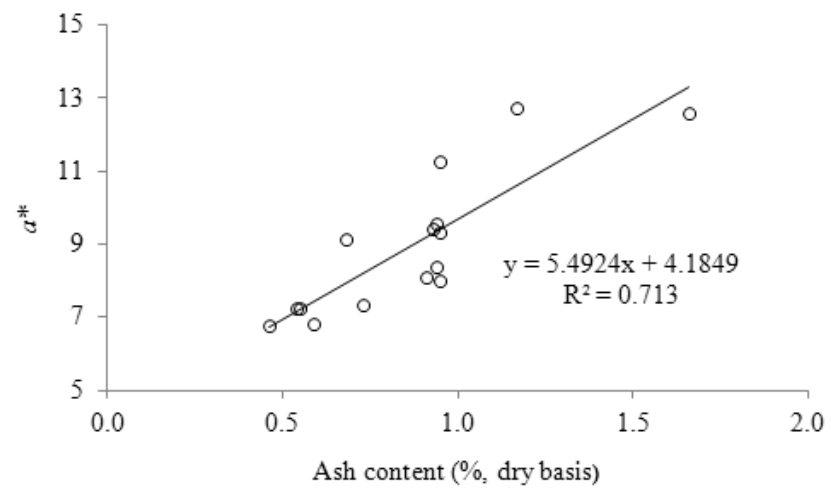

Fig. 3. Relationship between the ash content and redness of pasta.

The measurement results of the mechanical properties of spaghetti obtained based on the bending test performed on single samples are shown in Table 4. The maximum deflection of spaghetti ranged from 4.6 (sample XV) to $9.3 \mathrm{~mm}$ (sample V). For the same samples of pasta, the highest and the lowest flexural strength value was observed (23.3 and 48.9 $\mathrm{MPa}$, respectively). Pasta made of common wheat was characterised by similar strength parameter values to spaghetti from durum wheat. Statistical analysis revealed significant correlations between the mechanical properties of spaghetti and pasta density. A positive coefficient of correlations was seen between the density of the raw spaghetti and the maximum deflection of the centre of the spaghetti, 
T a b l e 4. Mechanical parameters of pasta determined on the basis of the bending test

\begin{tabular}{|c|c|c|c|c|c|c|}
\hline Sample & $h_{\mathrm{ma}} \mathrm{x}(\mathrm{mm})$ & $F_{\max }(\mathrm{N})$ & $W d(\mathrm{~mJ})$ & $\sigma(\mathrm{MPa})$ & $F_{c}(\mathrm{~N})$ & $W_{c}(\mathrm{~mJ})$ \\
\hline I & $5.32 b \pm 0.61$ & $0.82 \mathrm{bc} \pm 0.06$ & $4.22 \mathrm{~d} \pm 0.4$ & $27.62 \mathrm{~b} \pm 2.5$ & $1.05 b c \pm 0.08$ & $0.65 \mathrm{~b} \pm 0.07$ \\
\hline II & $6.58 \mathrm{c} \pm 0.72$ & $1.03 \mathrm{de} \pm 0.12$ & $3.18 \mathrm{c} \pm 0.3$ & $32.83 \mathrm{c} \pm 2.9$ & $1.00 \mathrm{~b} \pm 0.06$ & $0.71 b c \pm 0.05$ \\
\hline III & $7.62 \mathrm{~d} \pm 0.78$ & $1.08 \mathrm{e} \pm 0.10$ & $4.33 \mathrm{~d} \pm 0.4$ & $38.76 \mathrm{~d} \pm 3.5$ & $0.98 b \pm 0.07$ & $0.69 b \pm 0.06$ \\
\hline IV & $6.26 c \pm 0.73$ & $1.01 \mathrm{de} \pm 0.11$ & $3.71 \mathrm{~d} \pm 0.3$ & $34.64 c \pm 3.1$ & $0.99 b \pm 0.08$ & $0.84 \mathrm{bcd} \pm 0.08$ \\
\hline $\mathrm{V}$ & $9.27 \mathrm{e} \pm 1.05$ & $1.42 \mathrm{~g} \pm 0.17$ & $5.17 \mathrm{e} \pm 0.5$ & $48.92 \mathrm{e} \pm 4.4$ & $1.32 \mathrm{e} \pm 0.11$ & $1.18 \mathrm{f} \pm 0.08$ \\
\hline VI & $5.62 b \pm 0.63$ & $0.93 \mathrm{~cd} \pm 0.11$ & $3.30 \mathrm{c} \pm 0.3$ & $31.08 \mathrm{bc} \pm 2.8$ & $1.09 \mathrm{~b} \pm 0.09$ & $0.83 \mathrm{bcd} \pm 0.09$ \\
\hline VII & $6.33 c \pm 0.66$ & $0.71 b \pm 0.07$ & $2.41 \mathrm{~b} \pm 0.2$ & $24.94 a \pm 2.2$ & $1.06 b c \pm 0.08$ & $0.86 \mathrm{bcd} \pm 0.07$ \\
\hline VIII & $6.92 \mathrm{c} \pm 0.71$ & $1.22 \mathrm{f} \pm 0.11$ & $4.37 \mathrm{~d} \pm 0.4$ & $40.61 \mathrm{~d} \pm 3.6$ & $1.07 \mathrm{~b} \pm 0.12$ & $0.76 b c \pm 0.04$ \\
\hline IX & $6.70 c \pm 0.65$ & $0.48 \mathrm{a} \pm 0.06$ & $1.69 \mathrm{a} \pm 0.2$ & $29.77 b \pm 2.7$ & $0.43 a \pm 0.04$ & $0.34 \mathrm{a} \pm 0.02$ \\
\hline $\mathrm{X}$ & $7.93 \mathrm{~d} \pm 0.78$ & $1.52 \mathrm{~g} \pm 0.10$ & $5.73 \mathrm{e} \pm 0.5$ & $44.62 \mathrm{e} \pm 4.0$ & $1.65 \mathrm{e} \pm 0.13$ & $1.23 \mathrm{f} \pm 0.16$ \\
\hline XI & $5.60 \mathrm{~b} \pm 0.60$ & $0.98 \mathrm{de} \pm 0.12$ & $2.76 \mathrm{c} \pm 0.2$ & $30.30 \mathrm{~b} \pm 2.7$ & $1.29 \mathrm{~d} \pm 0.10$ & $1.08 \mathrm{f} \pm 0.11$ \\
\hline XII & $9.04 \mathrm{e} \pm 1.03$ & $1.41 \mathrm{~g} \pm 0.15$ & $5.22 \mathrm{e} \pm 0.5$ & $40.94 d \pm 3.7$ & $1.52 \mathrm{e} \pm 0.13$ & $1.19 \mathrm{f} \pm 0.09$ \\
\hline XIII & $5.42 b \pm 0.63$ & $1.12 \mathrm{de} \pm 0.12$ & $4.04 \mathrm{~d} \pm 0.4$ & $30.49 b \pm 2.7$ & $1.59 \mathrm{e} \pm 0.11$ & $1.09 \mathrm{ef} \pm 0.08$ \\
\hline XIV & $7.68 \mathrm{~d} \pm 0.73$ & $0.52 \mathrm{a} \pm 0.03$ & $2.23 b \pm 0.2$ & $30.41 b \pm 2.7$ & $0.52 \mathrm{a} \pm 0.06$ & $0.39 \mathrm{a} \pm 0.05$ \\
\hline$X V$ & $4.63 \mathrm{a} \pm 0.52$ & $0.87 \mathrm{~cd} \pm 0.06$ & $3.19 \mathrm{c} \pm 0.3$ & $23.26 \mathrm{a} \pm 2.1$ & $1.08 b c \pm 0.14$ & $0.91 \mathrm{cde} \pm 0.08$ \\
\hline
\end{tabular}

$h_{\max }$ - the maximum deflection of the center of the spaghetti, $F_{\max }$ - maximum force, $W_{d}$ - work of the deformation, $\sigma$ - flexural strength, $F_{c}$ - cutting force, $W_{c}$ - cutting work. Other explanations as in Table 1.

its maximum force, deformation work and flexural strength $(0.83 ; 0.74 ; 0.71 ; 0.95$, respectively). An example of the relationship between pasta density and flexural strength is shown in Fig. 4. In the literature on the subject, very few studies refer to pasta density and its correlations with quality. Pasta density depends on the conditions of production, in particular, on the performance of compressor stations. It also has been shown that drying conditions have a significant impact on pasta density. Pasta dried at a higher temperature is characterised by a lower porosity and greater density (Mercier et al., 2011).

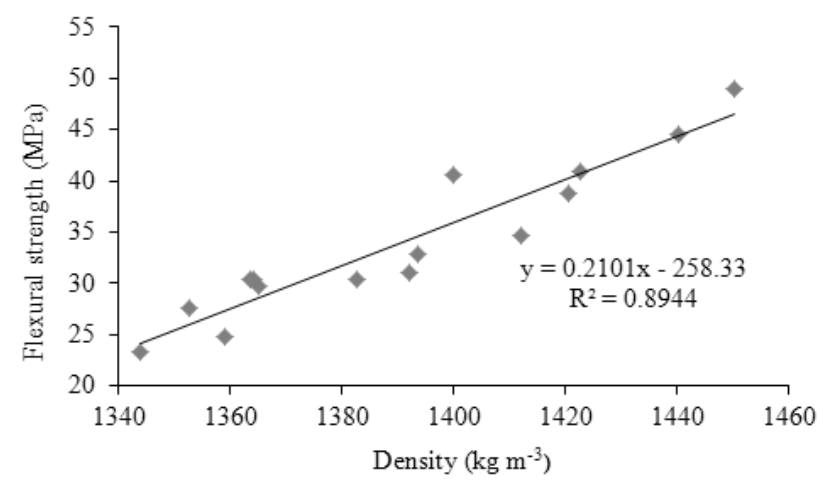

Fig. 4. Relationship between the density and flexural strength of pasta.
Pasta cutting force is a frequently determined parameter as it is an indirect indicator of pasta hardness, whereas cutting work is often referred to as 'pasta firmness' (Bouasla et al., 2016). The cutting force $F_{c}$ of cooked pasta ranged from 0.52 to $1.65 \mathrm{~N}$, whereas the cutting work $\left(W_{c}\right)$ changed from 0.34 to $1.23 \mathrm{~mJ}$ (Table 4). The results showed significant and positive correlation between $F_{c}$ and the destruction force $\left(F_{d}\right)$ for raw spaghetti $(\mathrm{R}=0.805)$, and between $W_{c}$ and $F_{d}(\mathrm{R}=0.835)$. An example of the relationship between $F_{d}$ and $F_{c}$ is shown in Fig. 5. This means that $F_{d}$ could also be an indirect indicator of pasta texture.

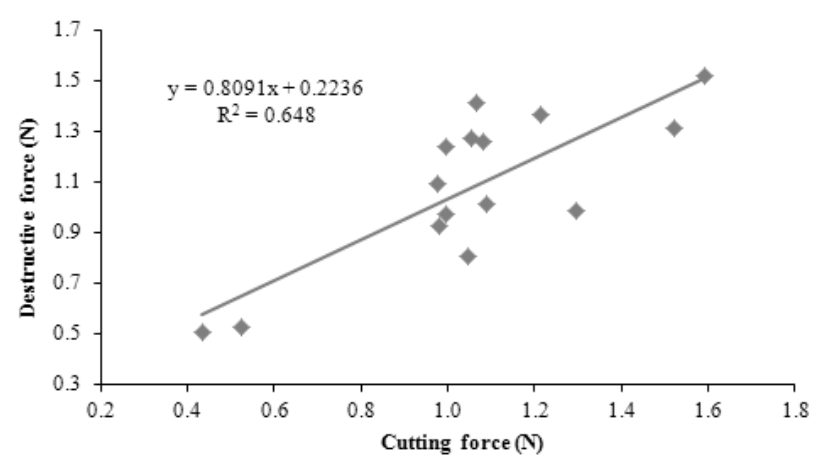

Fig. 5. Relationship between the cutting force and the destruction force for pasta. 


\section{CONCLUSIONS}

1. Significant correlations were found between pasta colour and ash content: as the ash content increased, the lightness of pasta decreased and redness increased.

2. The mechanical properties of raw pasta correlated positively with pasta density. The strongest correlation was found between pasta density and flexural strength.

3. The results showed that the colour attributes of raw pasta can be indicators of pasta cooking losses. The strongest correlation was found between pasta yellowness and cooking losses.

4. Most importantly, the destruction force for raw spaghetti correlated positively with the cutting force of cooked pasta.

Conflict of interest: The Authors do not declare conflict of interest.

\section{REFERENCES}

AACC, 2000. Approved Methods of the American Association of Cereal Chemists. AACC Inc., St. Paul, MN, USA.

Anese M., Cristina Nicoli M., Massini R., and Lerici C.R., 1999. Efects of drying processing on the Maillard reaction in pasta. Food Res. Int., 32, 193-199.

Aston L.M., Gambell J.M., Lee D.M., Bryant S.P., and Jebb S.A., 2008. Determination of the glycaemic index of various staple carbohydrate-rich foods in the UK diet. European J. Clinical Nutrition, 62(2), 279-285.

Biernacka B., Dziki D., Gawlik-Dziki U., Różyło R., and Siastała M., 2017. Physical, sensorial, and antioxidant properties of common wheat pasta enriched with carob fiber. LWT Food Science and Technology, 77, 186-192.

Bonomi F., D'Egidio M.G., Iametti S., Marengo M., Marti A., Pagani M.A., and Ragg E.M., 2012. Structure-quality relationship in commercial pasta: a molecular glimpse. Food Chemistry, 135, 348-355.

Bouasla A., Wójtowicz A., and Zidoune M.N., 2017. Glutenfree precooked rice pasta enriched with legumes flours: Physical properties, texture, sensory attributes and microstructure. LWT - Food Science and Technology, 75, 569-577.

Bouasla A., Wójtowicz A., Zidoune M.N., Olech M., Nowak R., Mitrus M., and Oniszczuk A., 2016. Gluten-free precooked rice-yellow pea pasta: Effect of extrusion-cooking conditions on phenolic acids composition, selected properties and microstructure. J. Food Sci., 81(5), C1070-C1079.

Debbouz A. and Doetkott C., 1996. Effect of process variables on spaghetti quality. Cereal Chemistry, 73(6), 672-676.

Del Nobile M.A., Baiano A., Conte A., and Mocci G., 2005. Influence of protein content on spaghetti cooking quality. J. Cell Sci., 41, 347-356.

Dziki D., Biernacka B., and Laskowski J., 2012. Influence of cooking time and common wheat flour addition to semolina on spaghetti mechanical properties (in Polish). Acta Agrophysica, 19(2), 277-287.
Dziki D. and Laskowski J., 2005. Evaluation of the cooking quality of spaghetti. Polish J. Nutrition Food Sci., 14, 153-158.

Feillet P., Autran J.C., and Icard-Verniere Ch., 2000. Pasta brownness: an assessment. J. Cereal Sci., 32, 215-233.

Güler S., Köksel H., and Ng P.K.W., 2002. Effects of industrial pasta drying temperatures on starch properties and pasta quality. Food Res. Int., 35, 421-427.

Hatcher D.W., Dexter J.E., and Fu B.X., 2008. Investigation of amber durum wheat for production of yellow alkaline noodles. J. Cereal Sci., 48, 848-856.

Hollgier A., 1963. Improved method for testing macaroni products. Cereal Chemistry, 40, 231-240.

Horváth Z.H. and Hodúr C., 2007. Colour of paprika powders with different moisture content. Int. Agrophysics, 21(1), 67-72.

Hrušková M., Švec I., and Sekerová H., 2011. Colour analysis and discrimination of laboratory prepared pasta by means of spectroscopic methods. Czech J. Food Sci., 29(4), 346-353.

Krishnan M. and Prabhasankar P., 2012. Health based pasta: redefining the concept of the next generation convenience food. Critical Reviews in Food Sci. Nutrition, 52, 9-20.

Larrosa V., Lorenzo G., Zaritzky N., and Califano A., 2016. Improvement of the texture and quality of cooked glutenfree pasta. LWT - Food Sci. Technol., 70, 96-103.

Lucisano M., Pagania M.A., Mariottia M., and Locatellib D.P., 2008. Influence of the material on pasta characteristics. Food Res. Int., 41(6), 646-652.

Martinez C., Pablo D., Risotta Alberto E., Leon M., and Amon Ch., 2007. Physical, sensory and chemical evaluation of cooked spaghetti. J. Texture Studies, 38, 666-683.

Mercier S., Villeneuve, S., Mondor M., and Des Marchais., 2011. Evolution of porosity, shrinkage and density of pasta fortified with pea protein concentrate during drying. LWT - Food Sci. Technol., 44(4), 883-890.

Migliori M., Gabriele D., De Cindio B., and Pollini C.M., 2005. Modelling of high quality pasta drying: quality indices and industrial application. J. Food Eng., 71(3), 242-251.

Ohm J.B., Ross A.S, Peterson C.J., and Ong Y.L., 2008. Relationship of high molecular weight glutenin subunits composition and molecular weight distribution of wheat flour protein with water absorption and color characteristics of noodle dough. Cereal Chemistry, 85, 123-131.

Raina C.S., Singh S., Bawa A.S., and Saxena D.C., 2005. Textural characteristics of pasta made from rice flour supplemented with proteins and hydrocolloids. J. Texture Studies, 36(4), 402-420.

Różyło R., Dziki D., Gawlik-Dziki U., Cacak-Pietrzak G., Miś A., and Rudy S., 2015. Physical properties of gluten-free bread caused by water addition. Int. Agrophys., 29(3), 353-364.

Sobota A., Rzedzicki Z., Zarzycki P., and Kuzawińska E., 2015. Application of common wheat bran for the industrial production of high-fibre pasta. Int. J. Food Sci. Technol., 50, 111-119.

Walsh D.E., 1971. Measuring spaghetti firmness. Cereal Sci. Today, 16, 202-206. 